\title{
Technical aspects of the radioimmunoassay of thyrotrophin
}

\author{
W. M. G. TUNBRIDGE, V. B. PETERSEN, AND D. R. WEIGHTMAN
}

From the Department of Medicine, Royal Victoria Infirmary, Newcastle upon Tyne

Since the early radioimmunoassays of serum thyrotrophin (TSH) (Odell, Wilbur, and Paul, 1965; Utiger, 1965) various technical refinements have led to assays of improved sensitivity, though few assays are capable of measuring subnormal levels of TSH (Patel, Burger, and Hudson, 1971; Hall, Amos, and Ormston, 1971). There are numerous variables in any radioimmunoassay but the important factors contributing to a successful assay are the quality of first antibody, the quality of labelled hormone, the assay conditions, the precipitation method, and not least the technical skill applied. These factors are reviewed here in relation to $\mathrm{TSH}$, and the evidence that has led to our current technique is outlined.

\section{Quality of First Antibody}

There are two main animal sources; rabbit antihuman TSH available from the National Pituitary Agency (NPA) or the Medical Research Council (MRC) and guinea-pig antihuman TSH prepared locally. Franchimont (1972) has also reported the use of antibodies to porcine TSH which crossreact with human TSH but this reagent is not generally available.

Locally produced guinea-pig anti-TSH is used at a final dilution of 1:600 000 which produces 50-70\% zero binding with reasonable sensitivity, and permits detection of TSH levels of the order of 0.5 to $1 \mu \mathrm{U} / \mathrm{ml}$ serum with a working range up to $50 \mu \mathrm{U} / \mathrm{ml}$. Further dilution of the antiserum may slightly improve the sensitivity of the assay but reduces the useful range of measurement.

Guinea-pig anti-TSH does not show significant crossreaction with luteinizing hormone $(\mathrm{LH})$ or follicle-stimulating-hormone (FSH) at levels seen in postmenopausal women (fig 1). There is therefore no need to add HCG to the system as is necessary with NPA rabbit antihuman TSH.

\section{Quality of Labelled TSH}

The main source of TSH for iodination is the NPA preparation. A modification of the method of Hunter

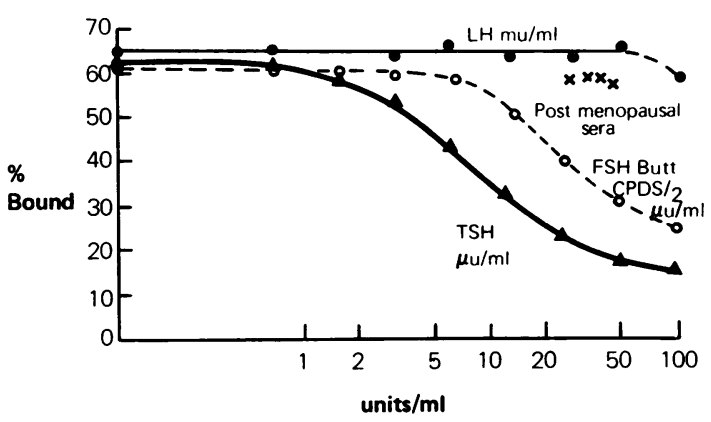

Fig 1 Test of specificity of TSH antibody: the apparent crossreaction with FSH is due to contamination of the FSH preparation with TSH as indicated by the lack of displacement when postmenopausal sera with high FSH levels are tested in the system.

and Greenwood (1964) is used for iodination (see table I); ${ }^{131} \mathrm{I}$ has been replaced by ${ }^{125} \mathrm{I}$ which appears to produce a more consistent label, and $1 \mathrm{mCi}^{125} \mathrm{I}$ reacting with $5 \mu \mathrm{g}$ TSH results in $85-95 \%$ incorporation with relatively little damage. Reducing the amount of chloramine $T$ reduces the amount of damage and $10 \mu \mathrm{g}$ is currently used. Exposure of ${ }^{125} \mathrm{I}$ and TSH to chloramine $\mathrm{T}$ for several minutes at $4^{\circ} \mathrm{C}$ instead of 15 seconds at room temperature does not appear to improve labelling. The smaller the volume of the reaction mixture the less damage is produced, and current iodination volume is $\mathbf{4 0} \mu \mathrm{l}$ after the addition of chloramine $T$. The reaction is stopped by the addition of $250 \mu \mathrm{g}$ of sodium metabisulphite.

Separation of pure 125I-TSH from damaged protein and free ${ }^{125} \mathrm{I}$ is carried out using a G-75

\begin{tabular}{lll}
\hline Materials & Quantity & Volume $(\mu l)$ \\
\hline NPA TSH & $5 \mu \mathrm{g}$ & 10 \\
125 I in 0.5M phosphate & $1 \mathrm{mCi}$ & 20 \\
Chloramine T & $10 \mu \mathrm{g}$ & 10 \\
Sodium metabisulphite & $250 \mu \mathrm{g}$ & 100 \\
\hline
\end{tabular}

Table I Iodination procedure 
fine Sephadex column. Various other grades of Sephadex and also Quso have been tried but a single $20 \mathrm{~cm}$ column of G-75 Sephadex gives the best separation. Damaged protein is eluted first and a fraction from the trailing edge of the peak ${ }^{125}$ I-TSH is selected for use in the assay. Electrophoresis of the reaction mixture gives a guide to the success of the iodination procedure. The binding and sensitivity of the assay is improved by using label of high specific activity and using small quantities, $100 \mathrm{pg}$ or less, of labelled TSH per assay tube.

Labelled TSH may be stored at $-20^{\circ} \mathrm{C}$, but its quality deteriorates after one week and even after repurification on a G-75 column the sensitivity of the repeat assay is reduced.

Successful iodination depends upon the use of freshly prepared materials and proper mixing in the reaction vial. Applying Butt's method of iodination (Butt, 1972) results in a very similar preparation of labelled TSH to that achieved by the method outlined above with no improvement in assay sensitivity.

\section{Assay Conditions (Table II)}

The MRC standard A TSH has now been replaced by the MRC standard 68/38 TSH which has similar characteristics. Standard TSH is 'serially diluted in $\mathbf{T}_{3}$-suppressed serum obtained from a normal volunteer who has taken $120 \mu \mathrm{g}$ tri-iodothyronine daily for one week. Comparison of test sera with standard diluted in buffer will result in erroneously high estimations of TSH levels as the standard curve is significantly depressed by the addition of serum.

\begin{tabular}{|c|c|c|}
\hline Materials & Quantity & $\begin{array}{l}\text { Volume } \\
(\mu l) \\
\text { per Tube }\end{array}$ \\
\hline $\begin{array}{l}\text { Guinea-pig antihuman TSH } \\
\text { diluted in carrier serum } \\
\text { 126I TSH }\end{array}$ & $\begin{array}{l}\text { Initial titre } \\
1: 100000 \\
100 \mathrm{pg}\end{array}$ & $\begin{array}{l}100 \\
100\end{array}$ \\
\hline $\begin{array}{l}\text { Standard TSH or test sera } \\
T_{2} \text { suppressed serum (for standard) } \\
\text { or TSH buffer (for test sera) } \\
\text { Second antibody + } 0.01 \mathrm{M} \text { EDTA }\end{array}$ & $\begin{array}{l}- \\
- \\
\text { Initial titre } \\
1: 10\end{array}$ & $\begin{array}{l}200 \\
200 \\
100\end{array}$ \\
\hline
\end{tabular}

Table II Assay composition

The TSH standards and test sera are incubated with the first antibody for 24 hours at $4^{\circ} \mathrm{C}$ before the addition of ${ }^{125}$ I-TSH, then for a further 48 hours at $4^{\circ} \mathrm{C}$ before the addition of the second antibody; 24 hours later the precipitate is centrifuged and counted. Too short or too long an incubation reduces the sensitivity of the assay. Each laboratory should determine the optimal incubation times before and: after the addition of labelled hormone which produce $\overrightarrow{\vec{j}}$ maximum assay sensitivity. Short assays have practical advantages and the above times reflect की compromise which allows a reasonably short assayes. without undue loss of sensitivity.

\section{Precipitation Method}

Rabbit anti-guinea-pig second antibody is preparedlocally but is also available commercially. The optimum titres of second antibody and guinea-pigcarrier serum (used to bulk the precipitate) should be determined in each laboratory. The use of labelledos gamma globulin to determine these titres may be misleading. It is better to determine the titre of the second antibody required to precipitate all the labelled hormone/first antibody complex (a) under? assay conditions and $(b)$ when excess first antibody $y_{2}$ is present. EDTA is added to bind calcium andw prevent complement interfering with the seconds antibody reaction. Whether EDTA is added initially or with the second antibody does not appear to affecty the assay.

\section{Quality of Assay (Fig 2)}

Standards and control sera are measured in triplicate Several estimations of a control serum indicate the within-batch variation which should be less than $\overrightarrow{5}$ $5 \%$. Controls from common pools of sera of known TSH content are included in consecutive assays to determine the between-batch variation at various. TSH levels. The sensitivity of an assay may be defined as the single smallest value whose fiduciaP

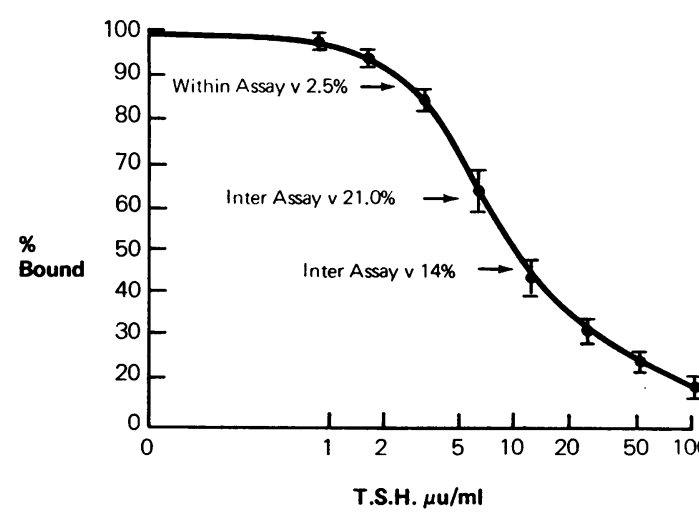

Fig 2 Quality of TSH assay: to facilitate comparison of successive standard curves the binding at zero concentration of TSH is expressed as $100 \%$. Mean $\pm 2 S E M$ (10 assays). 
limits for $\mathbf{P}=0.05$ do not include zero. The most satisfactory assays can detect $0.5 \mu \mathrm{U} \mathrm{TSH} / \mathrm{ml}$ serum. Over several assays the between-batch variation must be taken into account and the sensitivity is more commonly nearer $1 \mu \mathrm{U} \mathrm{TSH} / \mathrm{ml}$ serum. TSH can be detected in $80 \%$ of normal volunteers and the normal range in these subjects is $<1$ to $4.0 \mu \mathrm{U} / \mathrm{ml}$. A study of a randomly selected normal population is currently being undertaken to define the normal range more accurately. Whilst this assay does not detect subnormal TSH levels it is very useful in the exclusion of the diagnosis of primary hypothyroidism and in the recognition of the various grades of thyroid failure (Evered and Hall, 1972; Evered et al, 1973).

\section{References}

Butt, W. R. (1972). The iodination of follicle-stimulating and other hormones for radioimmunoassay. J. Endocr., 55, 453-454.

Evered, D., and Hall, R. (1972). Hypothyroidism. Brit. med. J., 1, 290-293.

Evered, D., Ormston, B. J., Smith, P. A., Hall, R., and Bird, T. (1973). Grades of hypothyroidism. Brit. med. J., 1, 657-662.

Franchimont, P. (1972). TSH immunoassay: assay factors affecting TSH levels. In Frontiers of Hormone Research, Vol. 1, 22-36. Karger, Basle.

Hall, R., Amos, J., and Ormston, B. J. (1971). Radioimmunoassay of human serum thyrotrophin. Brit. med. J., 1, 582-585.

Hunter, W. M., and Greenwood, F. C. (1964). A radioimmunoelectrophoretic assay for human growth hormone. Biochem. J., 91, 43-56.

Odell, W. D., Wilbur, J. F., and Paul, W. E. (1965). Radioimmunoassay of thyrotropin in human serum. J. clin. Endocr., 25, 1179-1188.

Patel, Y. C., Burger, H. G., and Hudson, B. (1971). Radioimmunoassay of serum thyrotrophin: sensitivity and specificity. $J$. clin. Endocr., 33, 768-774.

Utiger, R. D. (1965). Radioimmunoassay of human plasma thyrotropin. J. clin. Invest., 44, 1277-1286. 